\title{
Gelumpai Script: The Relevance of Value Solidarity in Palembang Society
}

\author{
Mayang Indah \\ Department of Teacher Training and \\ Education Sebelas Maret \\ University, Surakarta, Indonesia \\ Syarif Hidayatullah State Islamic \\ University Jakarta, Indonesia \\ Mayangindah1411@gmail.com
}

\author{
Hermanu Joebagio \\ Department of Teacher Training and \\ Education, Sebelas Maret University \\ Surakarta, Indonesia \\ Syarif Hidayatullah State Islamic \\ University Jakarta, Indonesia
}

\author{
Suryo Ediyono \\ Department of Teacher Training and \\ and Education, Sebelas Maret \\ University Surakarta, Indonesia \\ Syarif Hidayatullah State Islamic \\ University Jakarta, Indonesia
}

\begin{abstract}
Gelumpai script is stored in Balaputradewa Museum with inventory code 07.57. Gelumpai script was found in Baturaja Palembang huluan area. Gelumpai manuscript produced during the Sultanate of Palembang around the 16th-18th century AD. The Gelumpai manuscript shows the cultural system of the unique Palembang community in huluan area, it was written using the ka-ga-nga letters (Aksara Ulu/Rencong/ Surat Ulu/Ulu letter) that developed in Palembang, kromo inggil language (highest level in Javanese language) and it contained about praise to Prophet Muhammad. Literature study was used in this study. The researcher presented Gelumpai script as collective memories of Palembang community which contained social solidarity value of early Palembang society in the past.
\end{abstract}

Keywords--- Gelumpai script; Islam; collective memories; kaganga; kromo inggil; solidarity

\section{INTRODUCTION}

The island of Sumatra had a great civilization in its history in the past. Its strategic position as a trade route that connected it with the civilization centers in Asia, especially India and China [1]. Palembang is located in the southern part of Sumatra Island and became the largest city after Medan. Palembang in its history was once of the capital of the Sriwijaya kingdom. In inscriptions called as Kedukan Bukit which found in $683 \mathrm{AD}$, it showed the journey of Dapunta Hyang with his soldiers established the wanua (city). This inscription became a marker of the establishment of the Sriwijaya kingdom as the largest maritime kingdom and Buddha in the archipelago which controlled the western part of the Archipelago. On the other hand, Sriwijaya not only became the center of politics and government, but also as a center of knowledge, namely in the field of Buddhism. This was showed by the number of pastors who had been living in Palembang for years to learn the grammar of the Sanskrit language and to translate other religious texts in Chinese before sailing to India [2]. Sriwijaya not only experience rapid development in trade. It was supported by the strategic location of Sriwijaya on the east coast of South Sumatra, which is directly the opposite the Bangka strait and the trade routes between China and India [3].

Sriwijaya experienced a rapid development until the 14th century AD with abundant natural wealth such as spices: pepper, nutmeg, cloves, and other crops rubber, cotton, tobacco made them as main products for foreign traders. Trading was also a space of various nationalities, it was not only Palembang which became the center of the kingdom of Sriwijaya, and it also became crowded and visited by various nations. Majapahit expansion to the kingdom of Sriwijaya was in 1350 AD. This could be seen through the provision of tribute of Majapahit. Thus, Sriwijaya was under the Majapahit protection, although there was no charter that directly stated the existence of Majapahit power in Palembang [4].

The $16^{\text {th }}$ century became a new chapter after Islam flourished in the archipelago. Majapahit suffered slowly. This was marked by the emergence of Islamic kingdoms in the archipelago. Raden Fatah who was the descended from King Brawijaya V of King Majapahit then established the Demak sultanate. Under his leadership, Islam was growing rapidly, Islam as a religion was more easily accepted by people who lived in the archipelago, it was influenced by the social system that existed in Islam did not differentiate from each other. Demak became a great Islamic empire, but because of civil war the power of Demak suffered a decline and followers of Demak Sultan to Palembang and established the Sultanate of Palembang [5]

After the demolition of Demak, the descendants and followers of Demak fled to Palembang in the 16th century AD under the leadership of Prince Sedo Ing Lautan who later became the founder of the Sultanate of Palembang, but then under the protectorate of the Islamic Mataram Kingdom which controlled almost the entire island of Java. In the $17^{\text {th }}$ century AD Palembang Sultanate stood independently. The development of Palembang Sultanate coincided with the development of Islam in Palembang. Islam gave a new color in the life structure of the people of Palembang. Ulama had an important role in the life of Palembang palace. This could be seen from the number of Islamic texts and Islamic books made by keraton [6].

Palembang manuscript was written using paper, bamboo, and bark. For manuscripts derived from paper material written in addition to Javanese script was also written with Arabic script, while the script made from bark and bamboo using the aksara ulu/Ulu letters. Most of the content of the text was religious topics, although there was also a language, history and explained about a magical element [7]. One of the manuscripts produced during the Palembang sultanate was gelumpai script. Gelumpai script was stored in Balaputradewa Museum with inventory code 07.57. Using the material from 
the bamboo blade, with the script ulu, it was written in kromo inggil (high level of Javanese), and reciting the praise to the prophet Muhammad. This manuscript is a religious script found in the area of uluan Palembang namely Baturaja, South Sumatra. This manuscript showed the development of Islam in Palembang. On the other hand, the text also explained the value of solidarity contained in the manuscript. The value of solidarity in the script as collective memories which later became the binding of social solidarity of Palembang community.

\section{METHOD}

This is a descriptive-qualitative research trying to explain the traditional manuscript. its analytical unit was the Gelumpai script with inventory code 07.57. This manuscript was stored in Museum Balaputradewa Palembang. This manuscript belongs to a resident in the area of Baturaja, Ogan Komering Ulu, Palembang. The critical discourse analysis includes: (1) content (discourse) in text and (2) language used in the Gelumpai script; and (3) The mechanical solidarity value in Gelumpai script.

\section{RESULT AND DISCUSSION}

\section{A. Gelumpai script: Language and Islamic Discourse in Huluan area of Palembang}

Gelumpai script was a relic of the Sultanate of Palembang Darussalam which produced from the $16^{\text {th }}$ century until 18 AD. Gelumpai script came from bamboo material, it was written with a scratch technique using a knife. This manuscript used the ka-ga-nga letters, and used kromo inggil language and talked about the praise of Prophet Muhammad [8]. The Gelumpai script showed the social, political and religious dynamics of the Palembang Darussalam Sultan. In the Sultanate of Palembang, there were people who were from iliran and uluan area.

Both regions have cultural and social differences due to geographical landscape. The iliran area was close to the Musi River while the uluan area is the inland area. The iliran region was more openly accepted the change, this was due to the downstream area that became the door of foreign arrivals in Palembang. While the uluan regio was in the interior of Sumatra, it tends to be more traditional and closed [9].

Subsequently, Gelumpai manuscript was produced for uluan society which as a mean of Islam teaching in the area of Sultan environment [9]. The argument was proved in the Gelumpai script. Gelumpai manuscript showed ancient Javanese language $16^{\text {th }}-17^{\text {th }}$ century, it was from Demak to Sultan Agung. The production of this manuscript showed the cultural systemization of the iliran society to the community of uluan area.

In relation to this, Petters explained that Palembang community in everyday association used Malay dialect. Besides using the Malay dialect, there was a limited language vocabulary that developed in the palace of Palembang Sultan, the Java langua gehigh level in the Java language). The use of Java language showed the Javanese cultural system that was adopted by the Sultanate of Palembang. This was indicated by the use of diplomatic language using Javanese kromo inggil. The use of Javanese culture in Palembang palace as one of the efforts in maintaining the Javanese culture as the ancestor of the founder of the Sultanate of Palembang.

The use of Javanese kromo inggil was also found in several manuscripts in Palembang, such as the Gelumpai script with the inventory code 07.57. It was about the praise of Prophet Muhammad and the Charter of Padang Ratu 07.45 which contained about the regulation of life of Palembang community. Both of these manuscripts use the Middle Javanese, and some had been mixed with the local language of Palembang. This language showed the role of Java in the development of language in Palembang, until now, there are many languages that developed in Palembang and they have similarities with the Java language.

Both of the manuscripts above, the manuscripts which found in the huluan area of Sumatra. The position of the script was very important. It was not only showed the culture of literacy in the life of Palembang community. However, this perspective texts the representation of changes in the structure of the huluan society [10]. Besides the discourse in the text which contained the Islamization of Palembang huluan society. It was seen that blades number 4 and 7 mention the sentence of the shahadah and the guidance on the path of truth and distancing from disbelief.

Thus, Gelumpai script showed Javanese culture that had rooted in the life of Palembang society until now, it could be seen from the language that developed in the life of Palembang community. In addition, the discourse in the text was not merely as a religiosity aspect but also concerned the aspect of loyalty to the stakeholders, namely Palembang Sultanate. Irwanto mentioned that every Lebaran day/Eid Fitr day, the community of huluan performed the tradition of milir sebah that was giving tribute to the downstream area (Palembang Sultanate), and the feedback was downstream giving protection to the huluan community. Thus it can be concluded that the Gelumpai script which explained about the discourse of Islamization in Palembang huluan society, but on the other hand there was the discourse of political unity of the huluan region to the downstream area (Palembang sultanate).

\section{B. The Solidarity Value in Gelumpai script}

Gelumpai script with inventory code of 07.57 is a text that came from the writing tradition community huluan Palembang. This text talked about stories to praisethe prophet Muhammad. The position of the Gelumpai script became important in the structure of the Palembang huluan community. On the other hand, this manuscript contained the Islamization and discourse of political unity against the huluan region. In this perspective, the text of represent the changes the structure of huluan society [10].

This structural change was seen from the text of the text using the ka-ga-nga script which indicates the writing tradition of the Palembang community. The kromo inggil language in the text showed the influence of the Palembang Sultanate on language development within the structure of the 
Palembang community. Not only that the position of this manuscript contains the discourse of Islamization for the downstream community (Palembang sultanate) to the huluan community (inland Sumatra).

Gelumpai script consisted in 14 blades (bamboo). Each blade consists of 5-6 lines. The first began with the sentence (bismilah-irrahmanirehim). The manuscript was a collective memory of Palembang. According to Shazad [11], collective memory could be done by looking at historical media, one of them was a script. The script as collective memory of Palembang society showed that it had many values of life. One of the values contained in the Gelumpai script is the value of social solidarity.

Social solidarity refers to relationship between individuals or groups which based on shared moral feelings and beliefs reinforced by shared emotional experiences [12]. According Durkheim Social solidarity is divided into 2: social solidarity and organic social solidarity. Mechanical solidarity is formed on the basis of religious similarity, whereas organic social solidarity is formed on the similarity of needs, such as: work. The social solidarity that contained in the Gelumpai manuscript, it talk about mechanical social solidarity, it formed on the basis of religious thing. Anderson [13] said that early global solidarity was formed by religion Gelumpai script was as collective memory of Palembang society which had five components, namely (1) Self-respect/respect each other, (2) Security of life, (3) Social equality, (4) Human Brotherhood (5) become of justice. These five values were found in the Gelumpai script.

\section{(1) Self-respect, included in the $5^{\text {th }}$ slat}

Transcription:

//lan nuha Nabi Muhammad puniku angluhuri wong atuwa// Translation:

And he is the Prophet Muhammad (honoring) the parents

The $5^{\text {th }}$ slat contains self-respect value in which the prophet Muhammad is described as a figure who respects the parents. The history also acknowledges that the Prophet Muhammad has good attitude to parents, loves them, and definitely does something good to them. This value is relevant in everyday life. The attitude can be applied in our daily life that is respecting both parents, respecting friends, respecting teachers, and respecting the people around us. Further, people must have the attitude of being honor to others and tolerance of diversity that exist in Indonesia, especially in Palembang.

(2) Security of Life, included in the $7^{\text {th }}$ slat

Transcription:

//lan amimiti agama islam lan anuduha akenweng kasasan ing dadalan kang abener //lan asih ing tamuwan ajaken ing kardi islam agama sariyat // lan angaduhaken saking kapir//

Translation:

It is Islam that teaches that provides guidance to the right path and let us invite others with affection to the Shari'a of Islam and abstain from the infidel even unbeliever.
In the 7th line shows the attitude of security of life, the Prophet Muhammad is described as a person who has the nature of affection with others by referring to the right path that is Islam and distancing to disbelief. The concept of mutual protection can be applied in everyday life, for example: reminds each other about the dangers of pornography, drugs and free sex to the youth.

(3) Human brotherhood, included in the first slat Transcription:

//Nabi muhammata lan asihing miskin lan asih ing mukmin lan angapura sasakahing dusa manusiya ing utus dining ellah //

Translation:

Prophet Muhammad and loves the poor and loves the believers and asks for forgiveness as much as possible the sins of men sent by God.

The script tells human brotherhood in which Prophet Muhammad has a character that loves the needy and forgives as much as human prayer. The prophet had a very high siblings feeling that is reflected in the history of the Prophet Muhammad, when the he was sick he always remembered his people. This attitude can be implemented in daily life with inviting people and relatives in social activities to help others who are affected by natural disasters, who are the poor or the needy. In addition, in schools can also be done by helping friends who have difficulty in learning, by making study groups to deal with some difficulties.

(4) Social equality, included in the $8^{\text {th }}$ slat

Transcription:

//nira tan na bener panembah nira tinarima dining ellah luwih saking weng akih// lan anut satitah hing ellah lan anutupi calakaning weng// lan anduwini sarirani//

Translation:

His prayers are accepted by God more than the common people and follow God's commandments and cover up the woe of people and have a sense of humanity

The $8^{\text {th }}$ bar shows the attitude of social equality. The attitude of social equality is reflected in the life of the Prophet Muhammad who does not distinguish one's position and cover the sins of his servant and has a high sense of humanity. In everyday life we could implement this attitude through not distinguish the social status of others, family background, and their economy. To illustrate: being friend with anyone regardless of the ethnic, religion, race, and culture.

(5) Become justice, included in the $14^{\text {th }}$ slat

Transcription:

//uga le angapura kalupute ning weng anginaki hatining weng//

Translation:

Also he kindly forgives people's mistakes, makes people happy In the slat number 14 contains the value of become justice. Prophet Muhammad in his history is described as a figure who 
is become justice. This is reflected in the history of the Prophet Muhammad during the dispute in the first laying for stone of Kabbah. At that time the prophet was a represent as one who decided the case for the seizure of the first laying for stone in Kabbah. We should implement this value in daily life to be fair to anyone regardless of position or strata owned by others, not discriminate friends and treat friends well and forgive each other.

Thus it can be concluded that the text media is one of the methods used in building collective memories. The Gelumpai script contains the value of social solidarity. Social solidarity built by Palembang community was based on religious similarity. This manuscript as described in the above explanation that the manuscript Gelumpai is a religious script made by the Sultanate of Palembang and adapted to Palembang huluan society. This manuscript formed the political unity of the first society based on religious ties under the sultanate of Palembang. In this text also contains values of social solidarity that is mutual respect, mutual protection, brotherhood, social equality and fair. This value is still very relevant in use.

\section{CONCLUSION}

The explanation above shows that Gelumpai script was a manuscript of diversity being produced during the Sultanate of Palembang around the 16th-18th century AD. This script was stored in Balaputradewa Museum with inventory code 07.57. Gelumpai script was written in bamboo, media which had 14 bamboo blades. Gelumpai script used an alu script that was a local Palembang script, kromo inggil language (high level in Javanese) and reciting praise to the prophet Muhammad. Gelumpai script is collective memories of Palembang society, which contained social solidarity values. The values of social solidarity contained in the Gelumpai . The values of social solidarity were the attitude of, self-respect, security of life, social equality, human brotherhood, and become justice. Therefore, the script was as collective memory of Palembang community which then become the binding of solidarity attitude for the Palembang society.

\section{REFERENCES}

[1] A. Ikram, Jati Diri yang Terlupakan: Naskah-Naskah Palembang. Jakarta: Yayasan Naskah Nusantara. 2004.

[2] T. Iskandar, Kesusastraan Melayu Klasik Sepanjang Abad. Jakarta: Libra, 1999.

[3] P. M. Djoened, Sejarah Nasional Indonesia Jilid II dan III. Jakarta: Balai Pustaka.

[4] D. Hanafiah, Melayu-Jawa: Citra Budaya dan Sejarah Palembang. Jakarta: Grafindo. 1995.

[5] A. A. Munandar, Indonesia dalam Arus Sejarah Jilid II. Jakarta: PT. Ichtiar Baru van Hoeve, 2012.

[6] J. Peeters, Kaum Tuo-Kaum Mudo: Perubahan Religius di Palembang 1821- 1942. Jakarta: INIS. 1999.

[7] N. U. Kalsum, Aksara, Naskah dan Budaya Nusantara (Naskah Palembang). Jakarta: Indigo Media. 2017.

[8] D. Irwanto, Iliran dan Uluan: Dinamika dan Dikotomi Sejarah Kultural Palembang. Yogjakarta: Eja Publisher, 2010

[9] A. R. Igama, Gelumpai Tentang Nabi Muhammad (Koleksi Museum Balaputradewa). Palembang: Dinas Pendidikan Nasional Sumatera Selatan, 2005.

[10] J.O. Walter, Kelisanan dan Keaksaraan. Yogjakarta: Gading. 2013

[11] F. Shahzad, "Collective memories: a complex construction," Memory
Studies, 5 (4). 2011.

[12] Ritzer \& Smart. Handbook Teori Sosial. Jakarta: Nusa Media. 2012.

[13] A. Benedict. Imagined Commmunities: Komunitas-komunitas Terbayang. Yogjakarta: Pustaka Pelajar, 2008. 